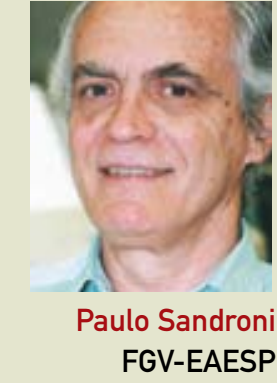

paulo.sandroni@fgv.br

\title{
Os custos da epidemia
}

FUNCIONÁRIOS PÚBLICOS NO BRASIL SÃO ALVO DE ESCANDALOSOS EXEMPLOS DE DESPROPORCIONALIDADE NO USO DO DINHEIRO QUE NÃO LHES PERTENCE

0 dr. William Gorgas, médico que comandava o saneamento da área onde o Canal do Panamá estava sendo construído, foi chamado pelo coronel George W. Goethals, o todo-poderoso chefe da obra. Apreensivo, pois as relações andavam meio azedas, $\mathrm{O}$ médico se apresentou. O militar foi logo dizendo: "Nem mais um centavo para matar mosquitos! Cada um que o senhor matou custou mais de US\$ 10!".

O dr. Gorgas tremeu, mas arrancou forças Deus sabe de onde para responder: "E saiu barato! Imagine se um desses tivesse mordido o senhor?". O coronel resmungou algo, mas o médico continuou tendo recursos para transformar o canal numa das áreas mais seguras do mundo.

No início do século XX não existia vacina contra a febre amarela - como hoje não existe contra a dengue, que assola o Rio de Janeiro todo verão. A picada era assustadoramente letal. E o mosquito não escolhia entre ricos ou pobres, brancos ou negros, americanos ou panamenhos. Apenas os enterros eram feitos em cemitérios separados.

Esse episódio evoca a seguinte questão: quanto custa uma epidemia? É difícil responder, pois devemos acrescentar aos custos objetivos e atuariais das mortes (além dos hospitalares), ou dos dias não trabalhados pelos sobreviventes, também os danos subjetivos ou morais - e estes deságuam no poço do insondável. Os primeiros são muito elevados; os últimos, inconsoláveis.

Mas os custos de evitar uma epidemia são facilmente determináveis. E são baratinhos. Basta que as terapias sejam aplicadas continuamente e as campanhas contra o mosquito, desfechadas com o mesmo empenho com que se combate a inflação. Mas, em vez disso, o que vemos é uma verdadeira epidemia de custos, tão intoleráveis quanto a presença do mosquito, para dizer o mínimo.

Quando um ex-ministro da República gasta mais de $\mathrm{R} \$ 1.400,00$ em uma diária de hotel (no Brasil), reitores federais embelezam seus apartamentos com mais de R\$500 mil e compram malas na China por mais de $\mathrm{R} \$ 2.000,00$ e um governador aluga jatinho para passear com a família na Europa, além de gestos escandalosos, denotam evidente desproporcionalidade na utilização do dinheiro público. No Rio de Janeiro, as larvas do Aedes aplaudem, assistem calmamente a um Fla x Flu, pois estarão a salvo por mais uma temporada.

Atribui-se a Confúcio a indicação das quatro formas de aprender: a repetição, o trauma, o trauma da repetição e a repetição do trauma. Em matéria de dengue e febre amarela, nos últimos cem anos, já vivenciamos as quatro. Ao que parece, ainda não aprendemos o suficiente. Ou será que existe outra maneira que teria escapado ao grande sábio chinês? 